\title{
Disasters Characteristics; An Effective Factor in Risk Perception of Healthcare Middle Managers in Armed Forces: A Qualitative Study
}

Otoufi. $\mathrm{M}^{1}$

*Sharififar. S2

Pishgooie. $\mathrm{SAH}^{3}$

Habibi. $\mathrm{H}^{4}$

1- MSc Student in Emergency Nursing, Faculty of Nursing, Aja University of Medical Sciences, Tehran, Iran.

2- ( ${ }^{*}$ Corresponding Author) Ph.D., Health in Disasters and Emergency, Instructor, Health in Disasters and Emergency Department, Faculty of Nursing, Aja University of Medical Sciences, Tehran, Iran.

Email: s_sharififar@yahoo.com

3- Ph.D., of Nursing, Assistant Professor, Critical care Nursing Department, Faculty of Nursing, Aja University of Medical Sciences, Tehran, Iran.

4- MSc in Nursing, Instructor, Pediatric Department, Faculty of Nursing, Aja University of Medical Sciences, Tehran, Iran.

\begin{abstract}
Introduction: According to the increasing incidence of disasters in all countries and the emphasis on the Sendai framework for disaster risk reduction, recognizing such risks is an important step in increasing preparedness. Evidence suggests that healthcare system is not ready to deal with disasters. Disaster risk perception is a new and contextual concept, and no research is yet conducted in this area in Iran.
\end{abstract}

Objective: The present study aimed at identifying the characteristics of disasters as an effective factor in risk perception of healthcare middle managers in armed forces.

Materials and Methods: The current qualitative study was conducted in 2018 using the Graneheim \& Lundman conventional content analysis. Data were collected using in-depth semi-structured interviews. The interviews continued until data saturation. The interviews were immediately transcribed and coded into semantic units to form categories and subcategories based on similarities and differences. Participants were 20 healthcare middle managers in armed forces with a variety of specialties.

Results: After analyzing 20 semi-structured interviews with the healthcare middle managers, semantic units were summed up in 125 codes and 18 subclasses; then the subclasses were explained in three factors of inside hospital, outside hospital, and type of disaster.

Discussion and Conclusion: The obtained results represented different aspects of disasters and their impacts on the risk perception of healthcare middle managers in armed forces. Disasters, in particular, political riots, inside and outside hospital disputes, as well as certain events such as holding elections and political-religious gatherings may affect the risk perception of managers and, consequently, their measures even before they become a threat to armed forces health organizations. It seems that the differences are related to the underlying conditions of Iran, especially the armed forces medical organizations.

Keywords: Content Analysis, Disasters, Healthcare System, Middle Managers, Risk Perception. 


\section{ويز كىهاى بلايا عاملى مؤثر در درى از خطر مديران ميانى نظام سلامت در نيروهاى مسلح: نتايج يك مطالعه كيفى}

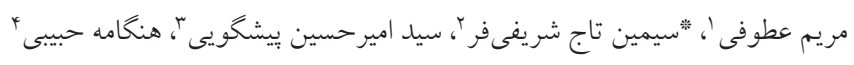

جكيده

مقدمه: با توجه به افزايش وقوع بلايا در تمام كشورها و تأكيد خار جوب كاهش خطر بلاياى سنداى (Sendai Framework)

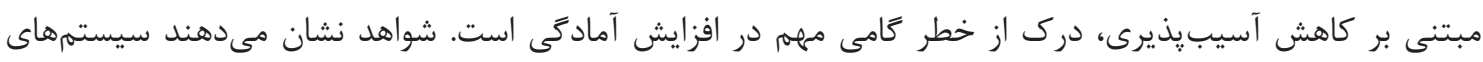

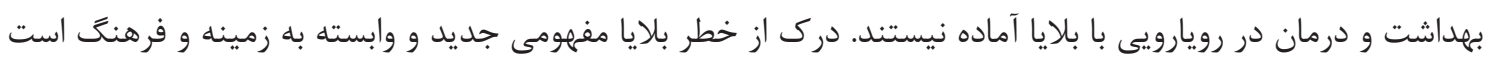
و در اين حيطه تاكنون يزوهشى در ايران انجام نشده است.

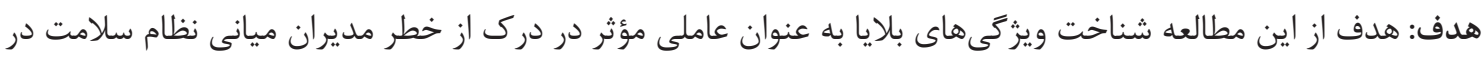
نيروهاى مسلح است.

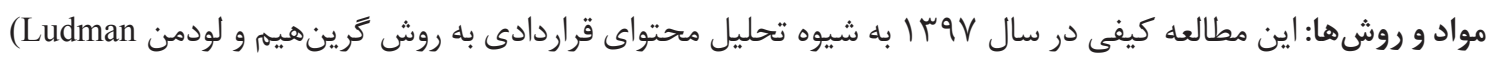
\& Graneheim)

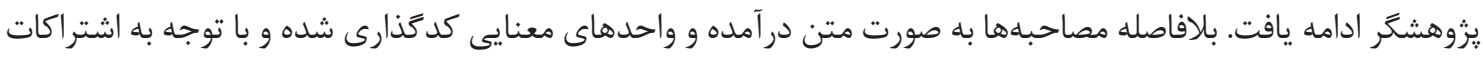

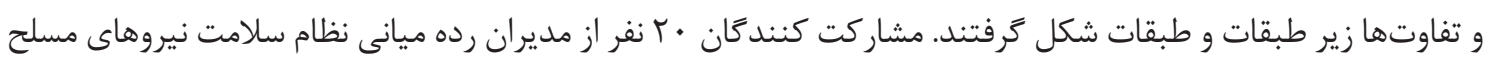
با طيفى از تخصصهاى مرتبط بودند.

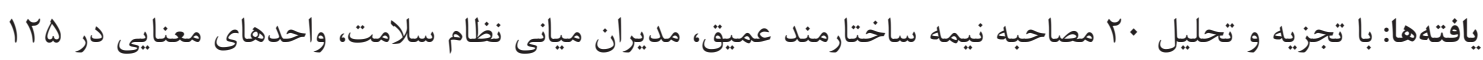

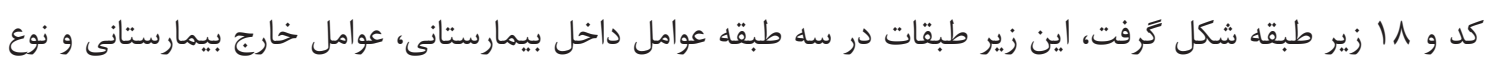
بلايا تبيين شدند. بحث و نتيجهَيرى: نتايج بيانكر جنبه هاى متفاوتى از بلايا و تأثير آن بر درى خطر مديران ميانى نظام سلامت نيروهاى

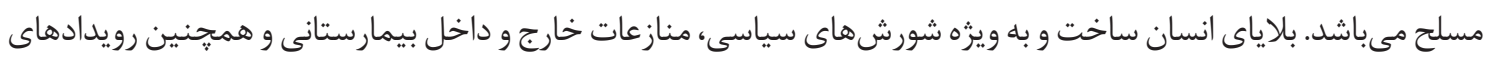

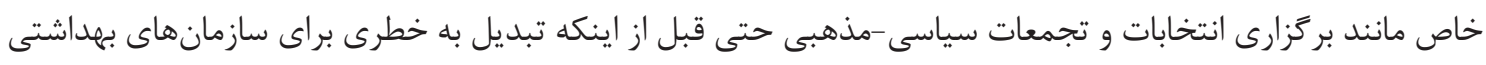

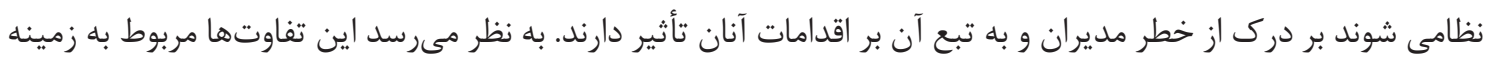

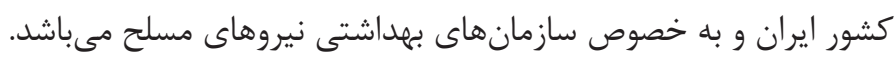

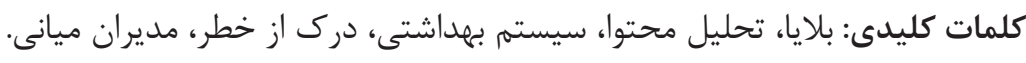

تاريخ دريافت:

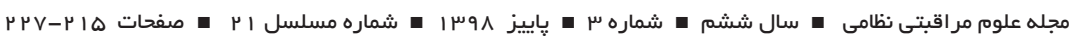

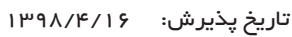

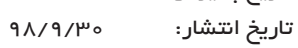

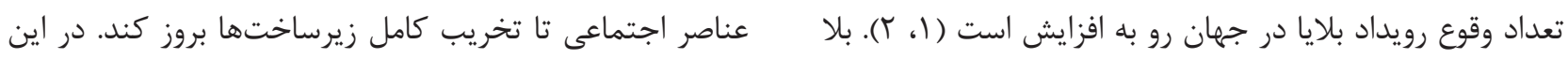


جهت ايجاد تابآورى ملل و جوامع در مقابل بلايا تصويب شده

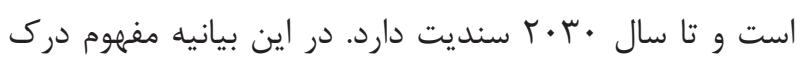

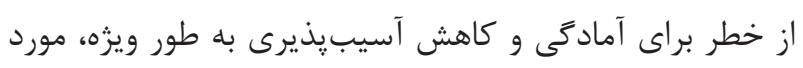

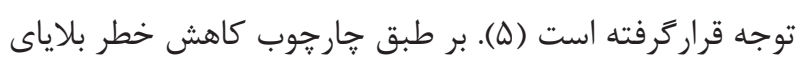
سنداى سياستها و رويههاى مديريت خطر بلايا بايد بر زايه

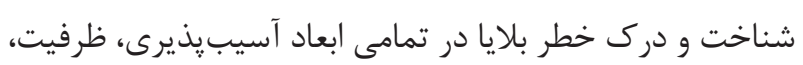
در معرض خطر بودن اشخاص و سرمايهها، ويزگى هاى مخاطرات

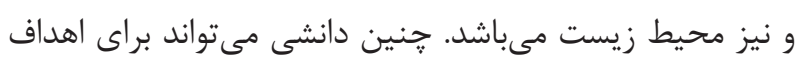

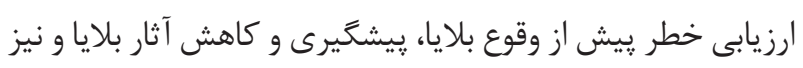
توسعه و اجراى برنامههاى آمادَى و پاسخكَويى مؤثر در برابر بلايا،

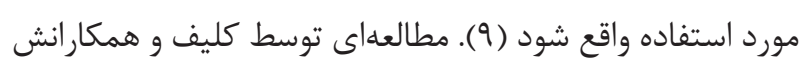
(J Cliff, B. et al)

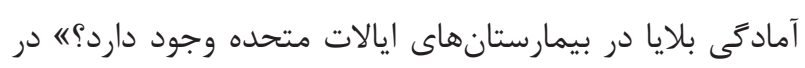

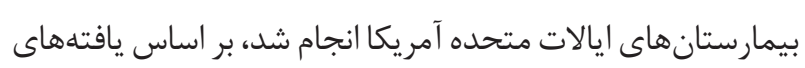

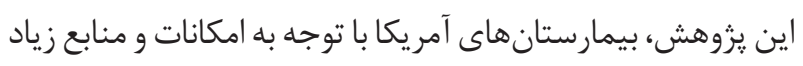

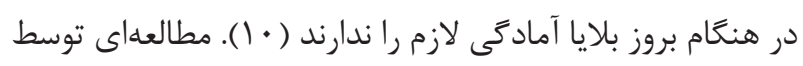
الزهرانى و همكارانش (Alzahrani) با عنوان آآمادكى يرستاران

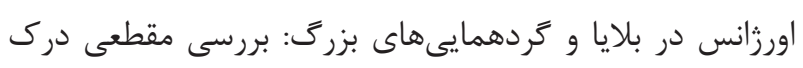

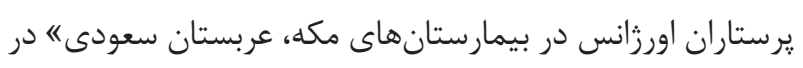
بيمارستان هاى عربستان سعودى انجام شده و نشان داد يرستاران

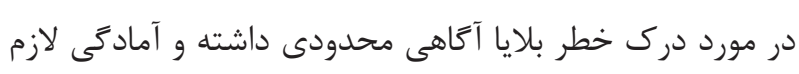

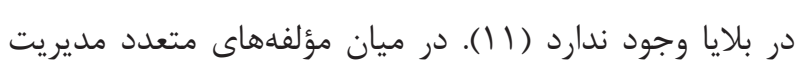

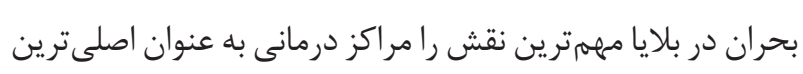

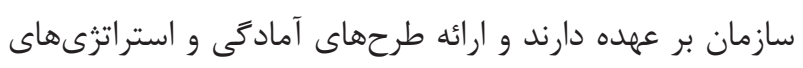

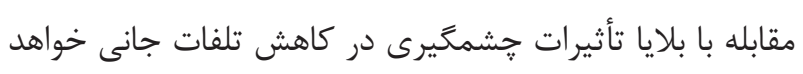

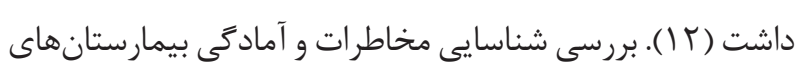

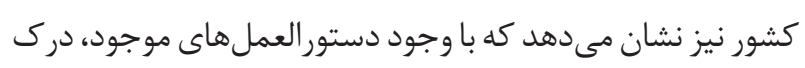

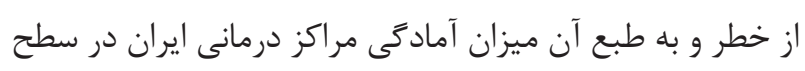

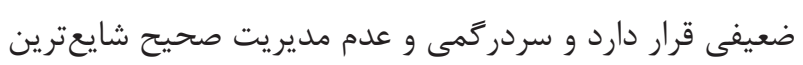

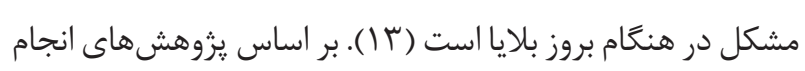

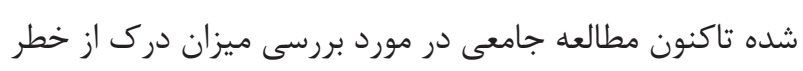

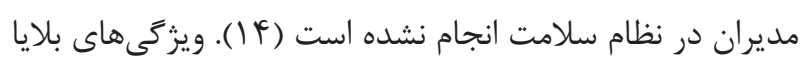
در بيمارستانهاى نظامى به دليل تنوع ماموريتهايشان بسيار

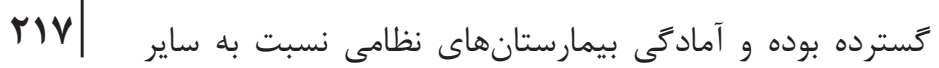

شرايط به دليل ناكافى بودن منابع و آمادگى، جوامع و سيستمهاى

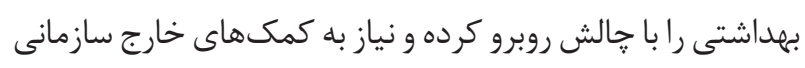

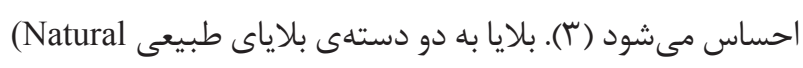
و و انسانساخت Disaster) مىشوند (f). بلاياى طبيعى يديدههايى غيرقابل اجتناب هستند

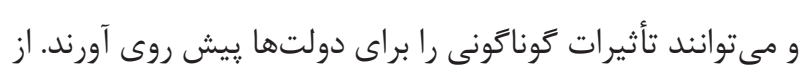

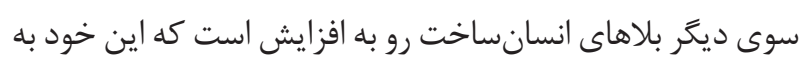

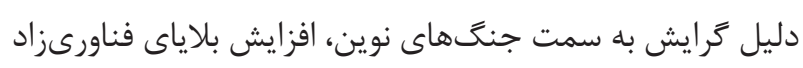
(Technological)

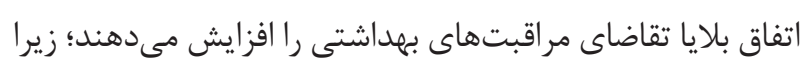

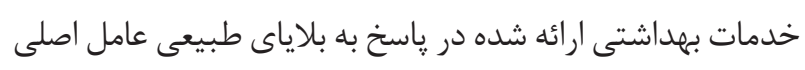

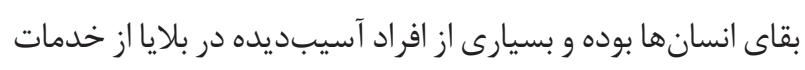

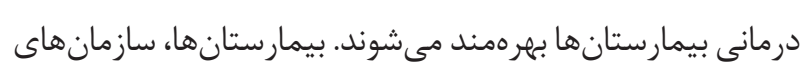

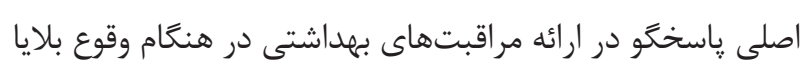

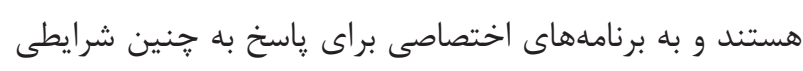

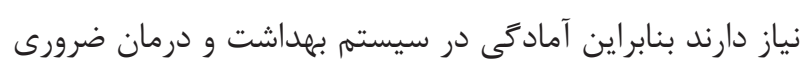
است (9). شواهد نشان مى دهد كه در همه كشور ها ميزان مواجهه

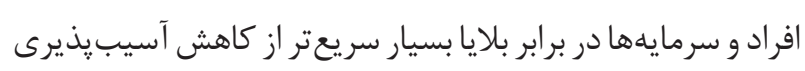

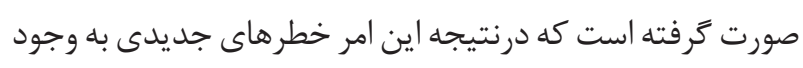
آمده و خسارات ناشى از بلايا بهطور مستمر افزايش يافته است.

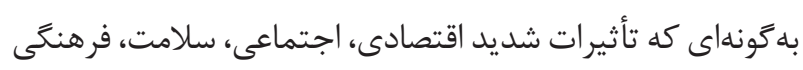

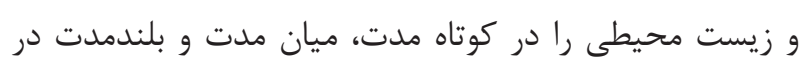
سطح جامعه بر جاى گذاشته است (V). با توجه به اين موضوع براى رسيدن به سطح آمادكى مطلوب و واهن

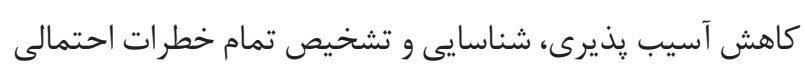

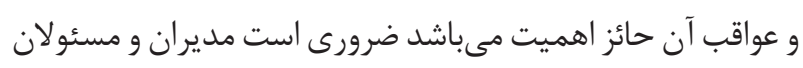

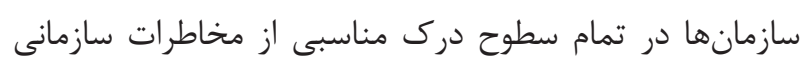

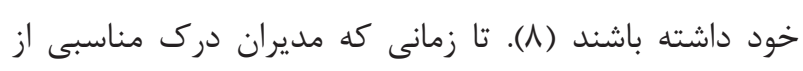

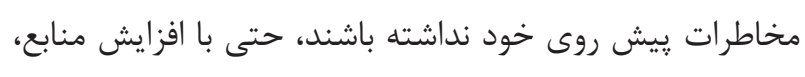

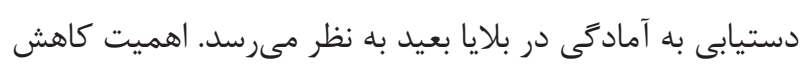
خطر بلايا تا حدى است كه در بازههاى زمانى مشخص، اسناد

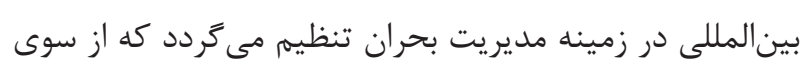

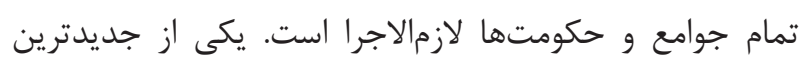

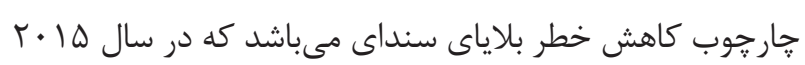


ارتباط بين سطوح عالى (مقامات) و سريرستى را بر عهده دارند،

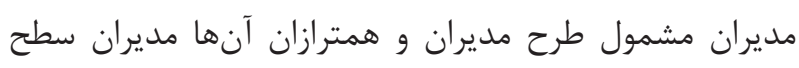

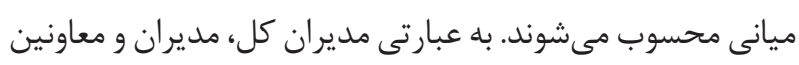

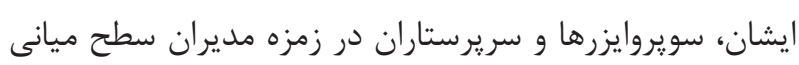

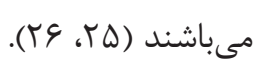

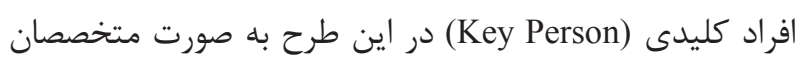
دانشخاهى، افراد با تجربه، مديران ميانى بيمارستان شامل معاون

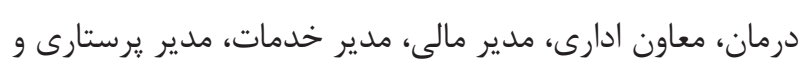

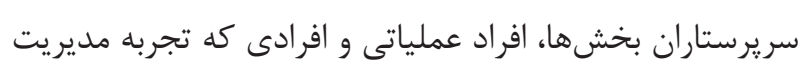

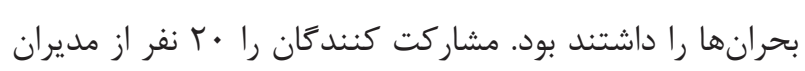
رده ميانى نظام سلامت نيروهاى مسلح با طيفى از تخصص رهاى

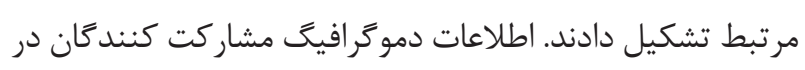
جدول شماره ا ذكر شده است.

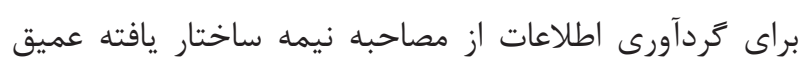

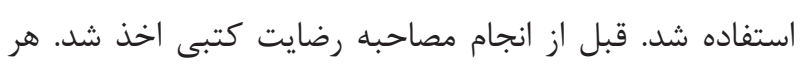

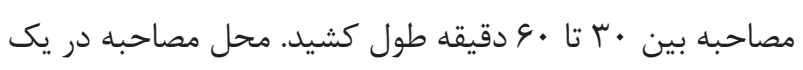

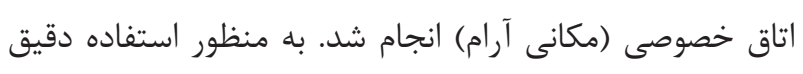

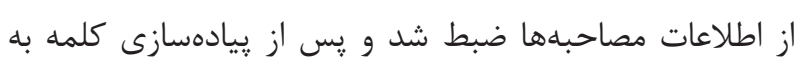
كلمه صداهاى ضبط شده جهت حفظ محرمانه بودن اطلاعات

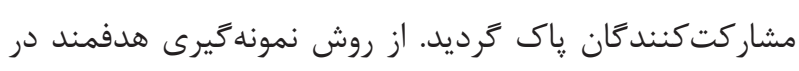

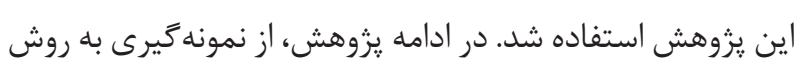

جدول ا - اطلاعات دموكر افيك مشاركت كنندَان

\begin{tabular}{|c|c|c|c|}
\hline درصد فراوانى & فراوانى & مورد سنجش & ويزَ \\
\hline$\% \Delta \Delta$ & 11 & 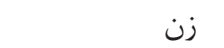 & \multirow{2}{*}{ جنس } \\
\hline$\% \notin$ & 9 & مرد & \\
\hline$\% \varphi$ & $\wedge$ & $r \cdot-r \cdot$ & \multirow{3}{*}{ سن } \\
\hline$\%$. & $\wedge$ & $r \cdot-\Delta \cdot$ & \\
\hline$\%$ & F & $\geq 0$ & \\
\hline$\% 10$ & r & دكترى تخصصى & \multirow{4}{*}{ تحصيلات } \\
\hline$\%$ & r & تخصص يزشكى & \\
\hline$\%$. & 4 & كارشناس ارشد & \\
\hline 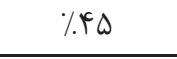 & 9 & كارشناسى & \\
\hline$\%$ & r & ستاد & \multirow{3}{*}{ محل خدمت } \\
\hline$\%$ & 1 & دانشعاه & \\
\hline$\% \wedge \Delta$ & IV & بيمارستان & \\
\hline
\end{tabular}

بيمارستانها براى كليه يرسنل از مديران كرفته تا يرستاران بسيار

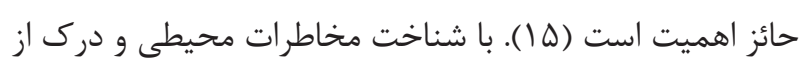

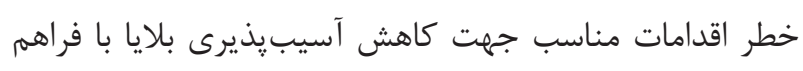
آوردن زيرساخت مناسب انجام مى گردد (• (1).

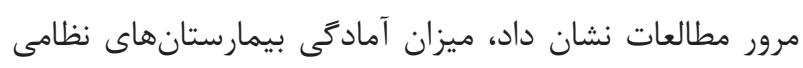

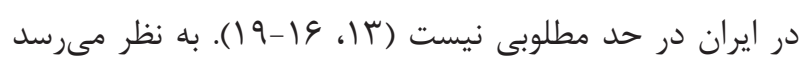

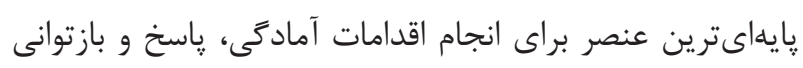

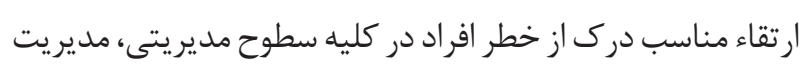

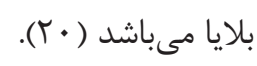

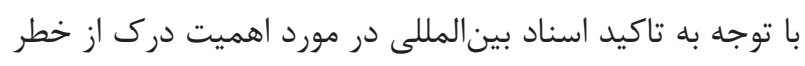
و تعهد كشور ايران در زمينه اقدامات مبتنى بر اين مقوله، ابتدا

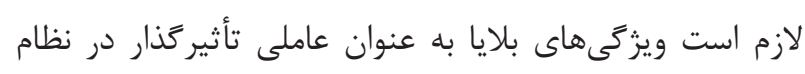

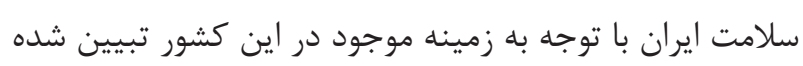
و تعريفى جامع و واحد در مقوله شناخت بلايا از ديد ذينفعان اندان استخراج كردد ( (Y). مفهوم درك از خطر در ادبيات مديريت بلايا

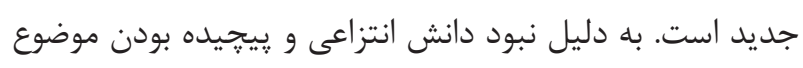

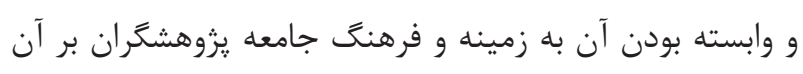

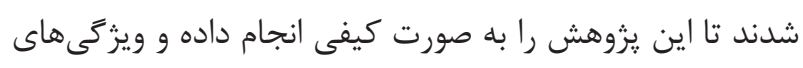

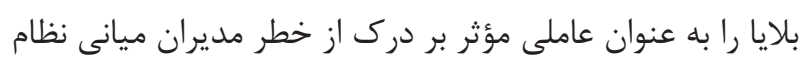
سلامت در حوزه مديريت بحران تبيين نمايند.

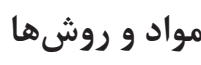

مطالعه حاضر از نوع تحليل محتواى كيفى با رويكرد قراردادى مونى

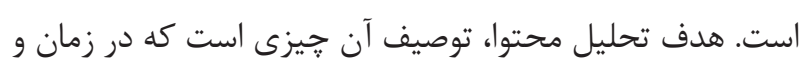

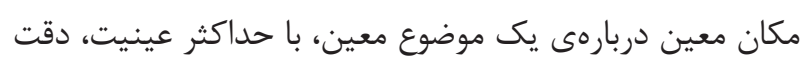

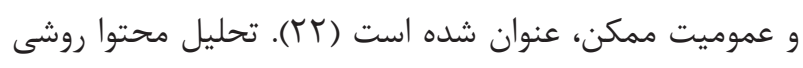
براى تفسير ذهنى محتواى دادهاى متنى از طريق فرايندى عند استى

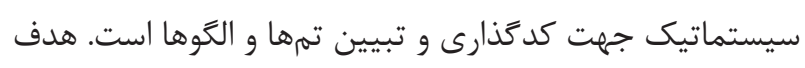

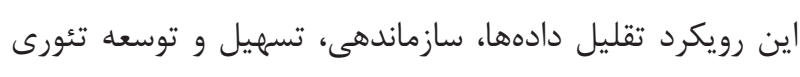

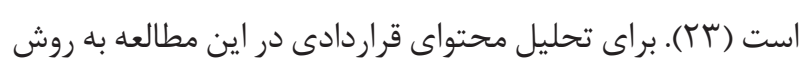

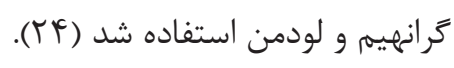

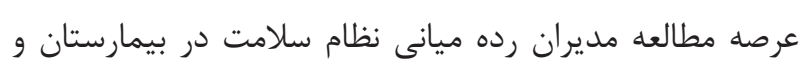

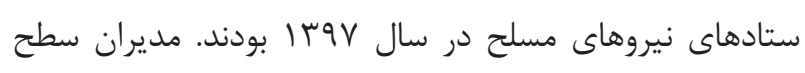

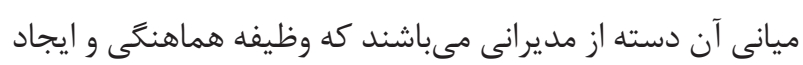


متون اجرا كرديد. در طى فر آيند كدَذارى نياز بود كدَذارى مرتباً

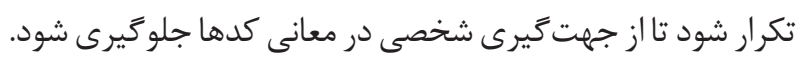

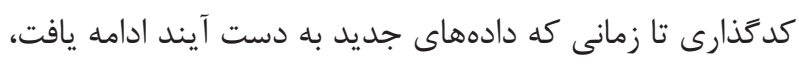
ممكن بود (حتى، حتماً) كه مضامين و مفاهيم جديد استخراج شده و به راهنماى كدَذارى اضافه كردند. در اين يزوهش پس از اتمام كدگذارى، ورود اطلاعات به رايانه، تجزيه و تحليل دادهها به صورت دستى انجام شد.

\section{دقت علمى و اعتبار دادهها (Rigor)}

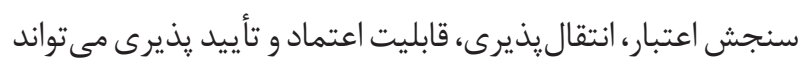

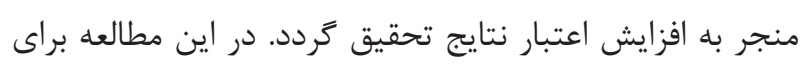

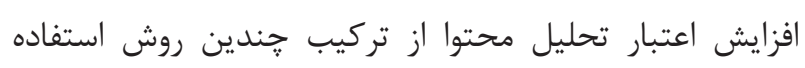
شد. يزوهش در مدت شش ماه انجام شد. در تمام مدت انجام

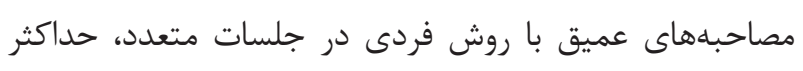

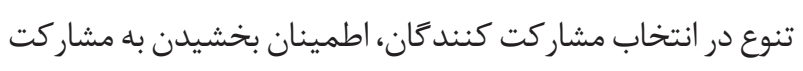

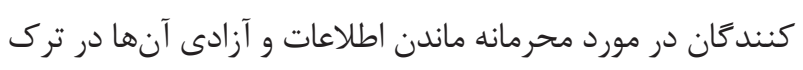

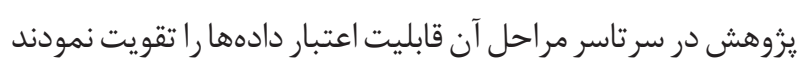

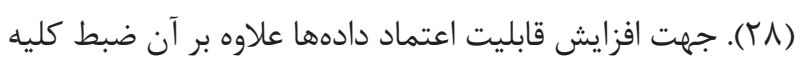
مصاحبهها و تبديل آنها به نسخ مكتوب، بازبينى دادهها توسط

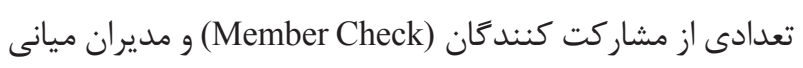
مطلع و با تجربه و اعضاى هيئت علمى مطلع در زمينه تحليل تحقيقات كيفى كه در تحقيق شركت نداشته اند، انجام شد. علاوه

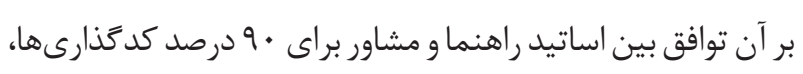

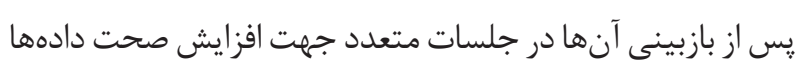

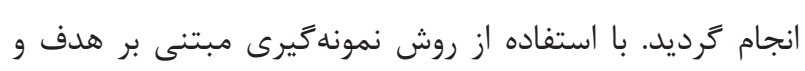
يوشش دادن كليه مديران رده ميانى نظام سلامت بر قابليت انتقال يافتههاى يزوهش افزوده شد. مر احل اجرايى كار به روشنى و وضوح

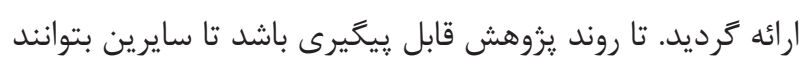

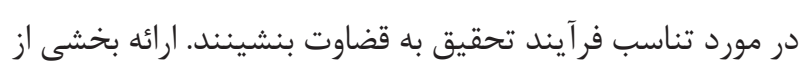
يافتهها طى جلسات يِرامون روند مصاحبه، سؤالات و كدها و نحوه

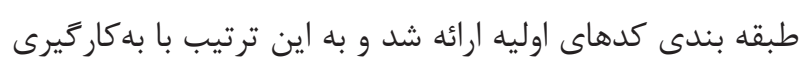

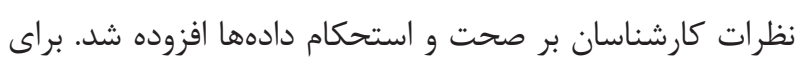
قابليت تائيد يذيرى يزوهشَّر در تمام مراحل جمعآ آورى و تحليل

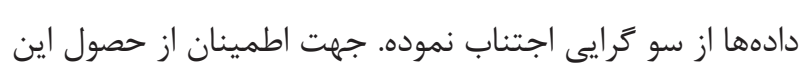

كلوله برفى استفاده شد. مصاحبه با مديران ميانى نظام سلامت

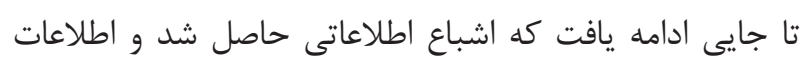

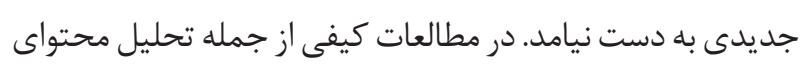
كيفى اغلب نغرانى در رابطه با تعيين حجم نمونه قبل از آغاز

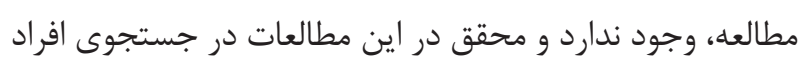

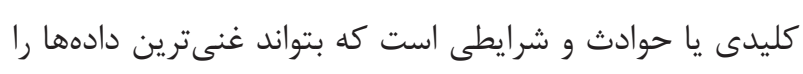
فراهم نمايد. نقطه قوت اين گونه مطالعات عميق بودن يافته آهاى

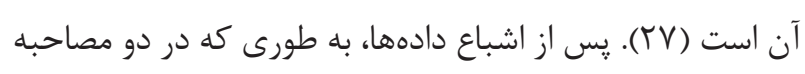

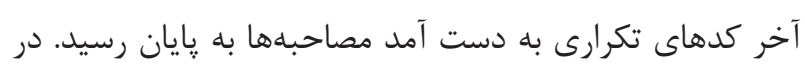

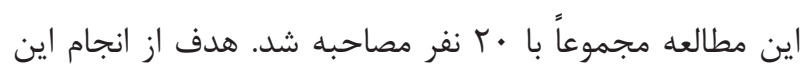

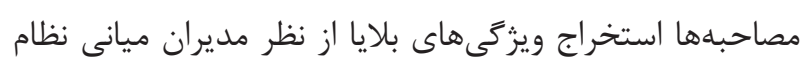
سلامت در نيروهاى مسلح بود.

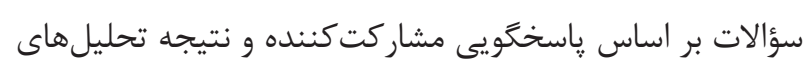

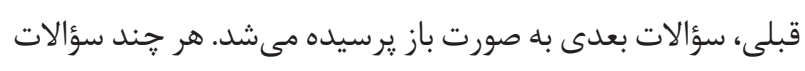

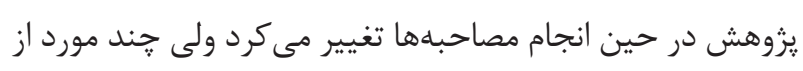
سؤالات به شرح ذيل مىباشد: به نظر شما در خه مواقعى سيستم هشدار بحران در سازمان

$$
\begin{aligned}
& \text { شما فعال مى كردد؟ } \\
& \text { شما جه رويدادهايى را بلا مى دانيد؟ }
\end{aligned}
$$

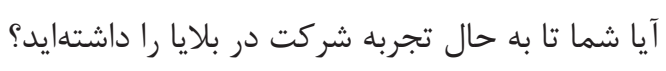
به نظر شما درك از خطر مديران جطور مىتواند به كنترل

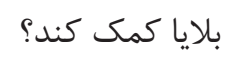
هِ از كسب رضايت آكاهانه در موضوع مشار كت در مطالعه و ضبط

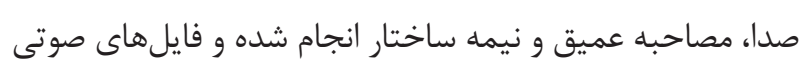

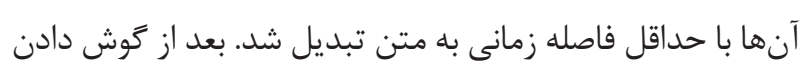
و مطالعه مكرر صوت و متن مصاحبهها، واحدهاى معنايى تعيين

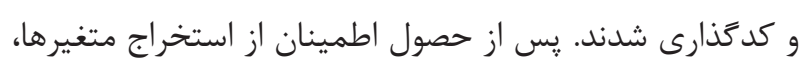

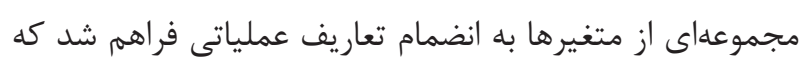

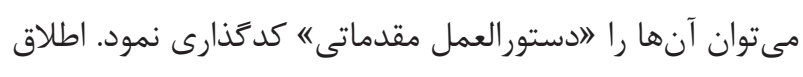

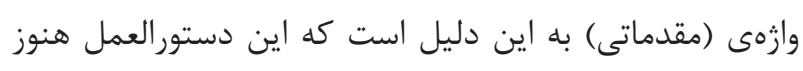

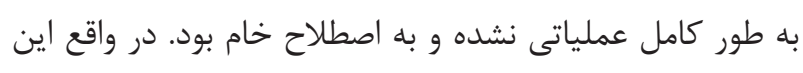

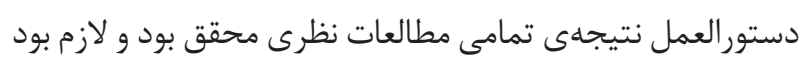

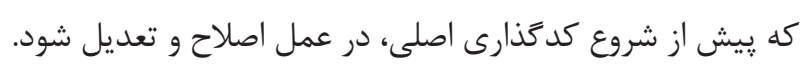

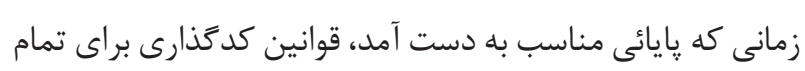


در اين يزوهش بود، به عقيده مشاركت كنند كان بحران هاى داخل

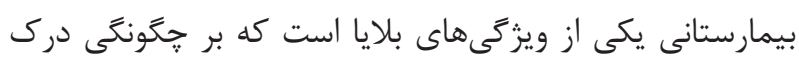

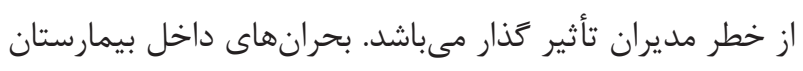

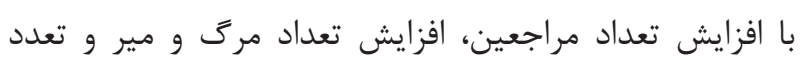

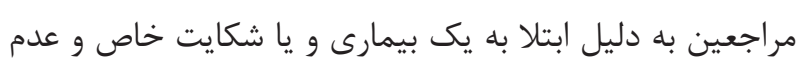

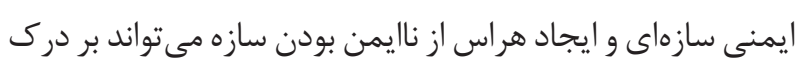
آنها از بلايا تأثير كذار باشد. افزايش تعداد مراجعين: تحليل دادها نشان داد كه در بحران بانهاي داخل بيمارستانى نيروهاى مسلح، افزايش تعداد مر اجعين به عنوان عاملى تعيين كننده در درك خطر مديران است. مراجعه تعداد

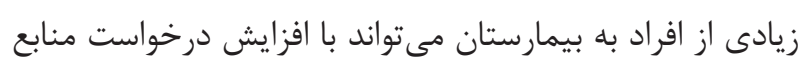
انسانى و تجهيزات بر روندهاى مديريتى بيمارستان مؤثر بوده و

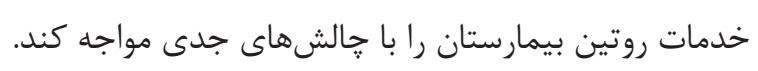

$$
\text { يكى از مشاركت كنندكان اظهار داشت: }
$$

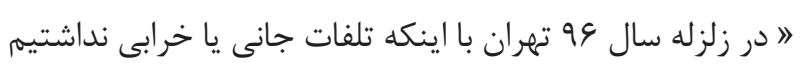

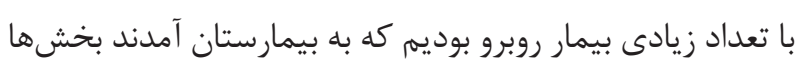

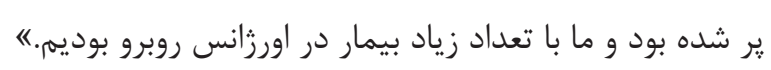

\section{|-1- افزايش تعداد مرگ و مير}

به عقيده مشاركت كنندگان، افزايش تعداد مرگ و مير خود به

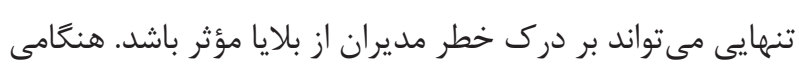
كه تعداد زيادى مرگ (بيش از تعداد معمول) در طى يك دوره زمانى رخ مىدهد، حكايت از ورود به بحران دارد. آنان معتقد بودند بايد براى رويدادهايى كه مىتواند جنين تأثيراتى داشته باشد، آماده بود. يكى از مشاركت كنندكان اظهار داشت: "جند سال پيش من در ICU كار مى كردم در طول دو هفته آمار

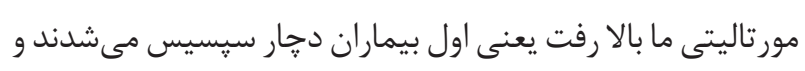
بعد فوت مى كردند يرسنل از اين وضع خيلى ناراحت بودند تقريباً هر دو روز يك يا دو فوتى داشتيمم بخش شرايط خوبى نداشت

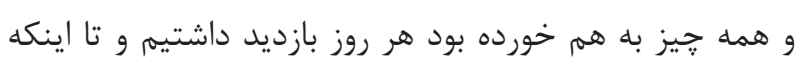
مشخص شد توى استريل كردن تجهيزات مشكل وجود دارد.»
امر، بخشى از مصاحبه ها و رونوشت آنها به همراه كدكذاري انجام

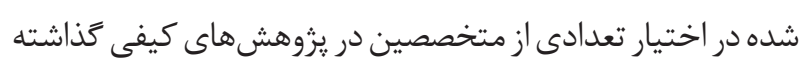

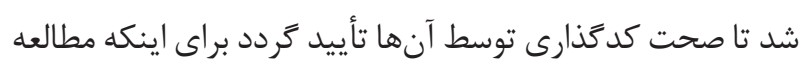

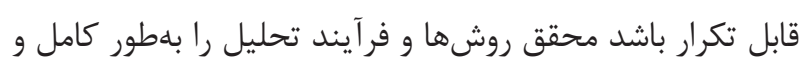

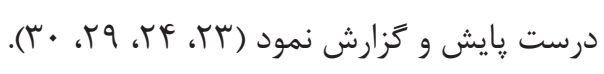

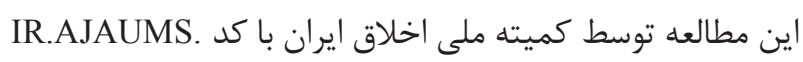

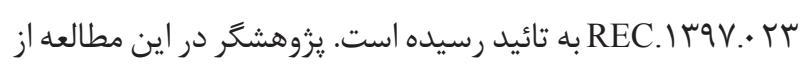
اصول و تعهدات اخلاقى، داوطلبانه بودن شركت افر اد در مطالعه و

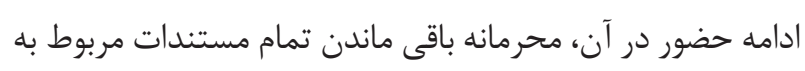

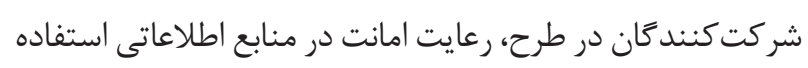

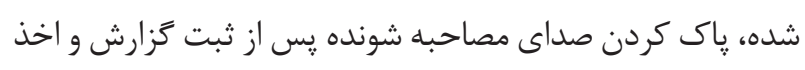
رضايت نامه كتبى از مصاحبهشونده و اخلاق نشر ييروى نمود.

يافته ها

״س از انجام مصاحبهها، يُيادهسازى و تجزيه و تحليل دادهها انجام

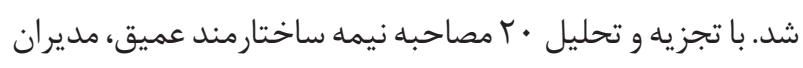

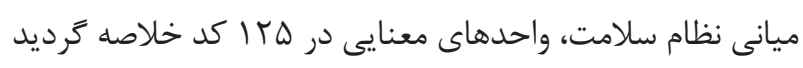

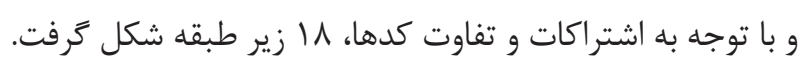
اين زير طبقات در سه طبقه عوامل داخل بيمارستانى، عوامل

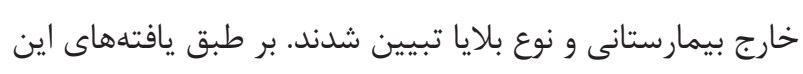

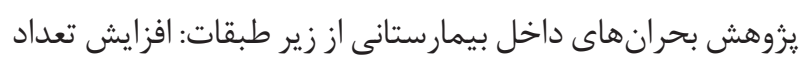

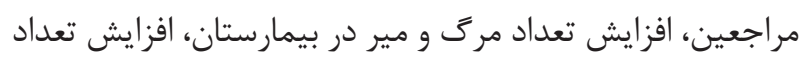
يك بيمارى خاص، عدم ايمنى سازه بيمار ستان در بلايا تشكيل شد.

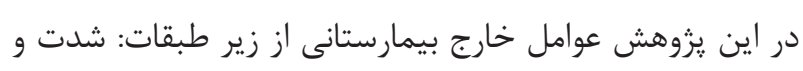

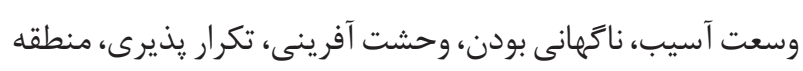

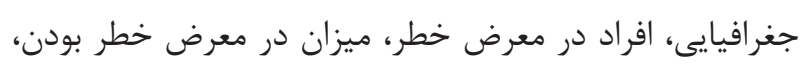

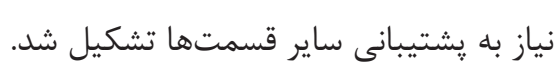

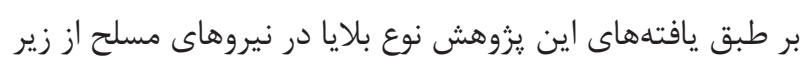

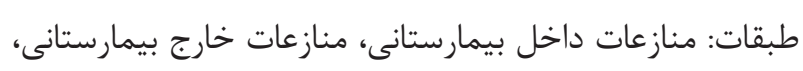
تجمعات سياسى-مذهبى، شورش هاى سياسى، بركزارى انتخابات و بلاياى طبيعى تشكيل شد.

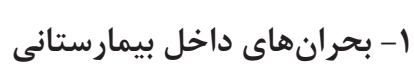
بحر انهاى داخل بيمارستانى يكى از طبقات اصلى به دست آمده 
در ساعات اوليه رويداد بلا به منطقه براى مديريت بلا، يشتيبانى، حمايت و حفظ امنيت شهروندان در منطقه دجار حادثه مىباشد.

\section{r-1- شدت و وسعت آسيب}

به عقيده مشار كت كنند كان، شدت و وسعت وست آسيب از عوامل تأثير

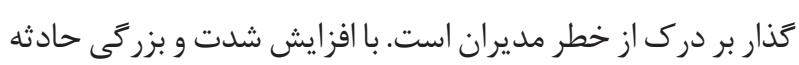

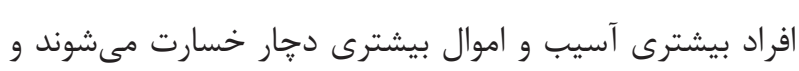
اين موضوع روى درك از خطر افراد تأثير مى كذارد. يكى از مشاركت كنند كان اظهار داشت:

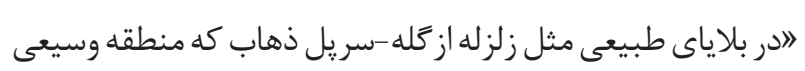

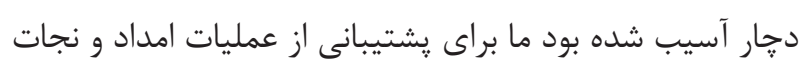
تجهيزات و نيروى انسانى به اين مناطق اعزام كرديم و هم مراكز

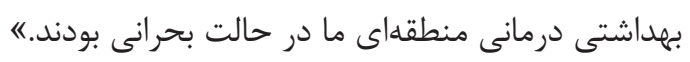

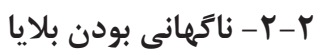

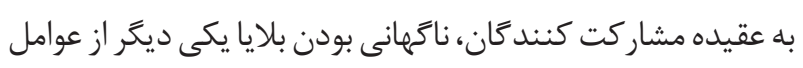

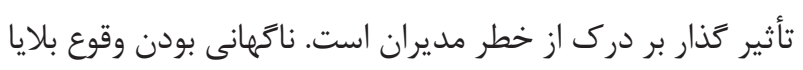
باعث ايجاد احساس خطر در مديران شده و باعث ايجاد آمادكى درى در سازمانهاى تحت نظر اين مديران مى كرددد. يكى از مشاركت كنند

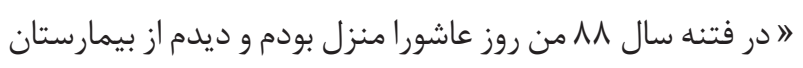
مرتب با من تماس مى گيرند وقتى به تلفنهم جواب دادم فراخوان زدند و وقتى من خودم را بيمارستان رساندم هم ديدم كه بيمارستان

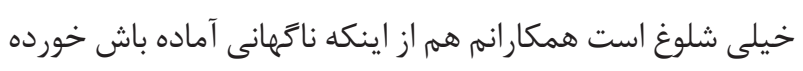

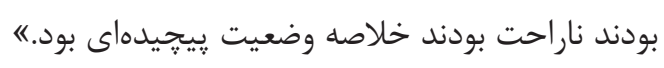

\section{r-r- وحشت آفرينى بلايا}

به عقيده مشاركت كنندكان، وحشت آفرينى بلايا يكى ديكر از

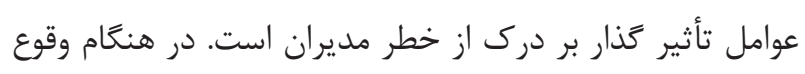

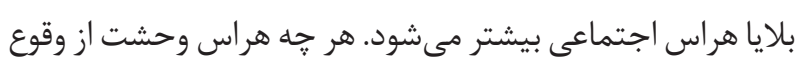

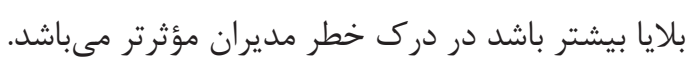

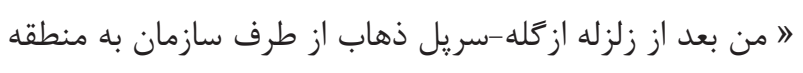
اعزام شدم در آن جا بيمارستان صحرايى زده شده بود شبر شها
اكثر مشاركت كنندكان معتقد بودند هر كاه تعداد زيادى مراجعه

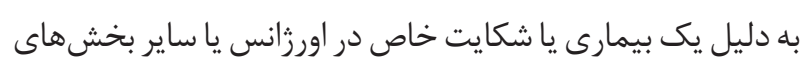

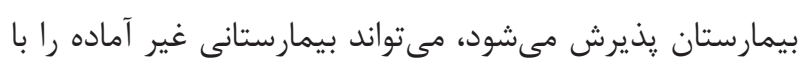
جالش روبرو كند. - جارن يكى از مشاركت كنند

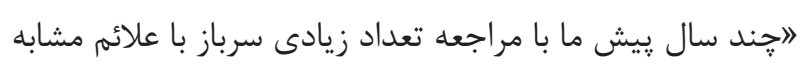

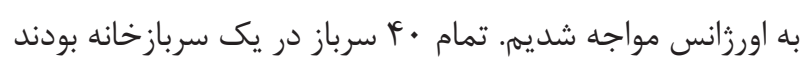

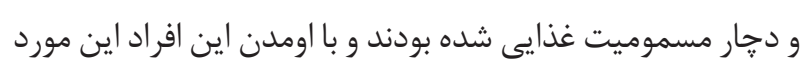

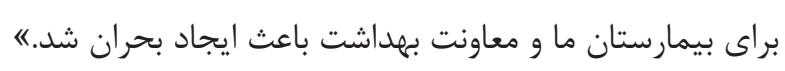

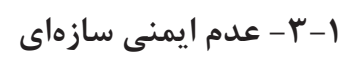

به عقيده مشاركت كنندَان، فرسودگى سازهاى بيمارستانها از عاز عوامل تأثير كذار بر درك از خطر مديران است. با افزايش احتمال

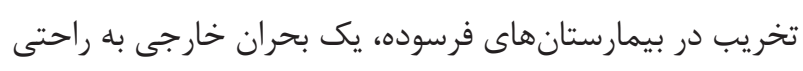
مى تواند تبديل به يك بحران داخلى شود. يكى از مشاركت كنند "انبودن ثبات اقتصادى و عدم بودجه كافى براى بازسازى ساختمان

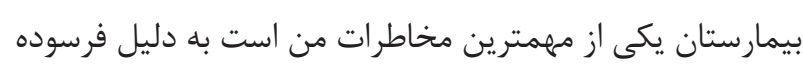

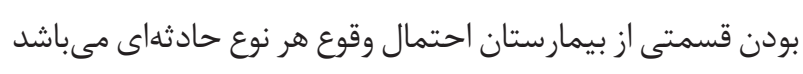

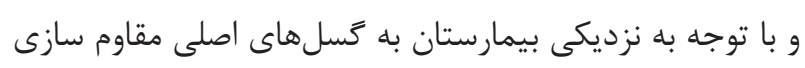
بيمارستان يكى از مهمترين اقدامات مى باشد به طورى كه كاركنان

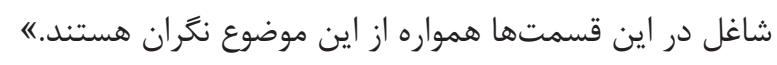

\section{r- بحر انهاى خارج بيمارستانى}

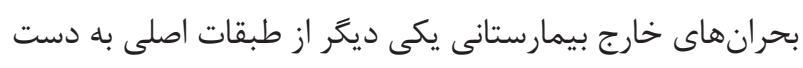

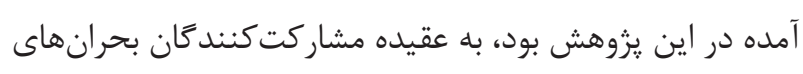

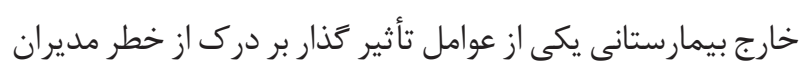

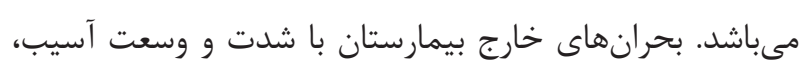

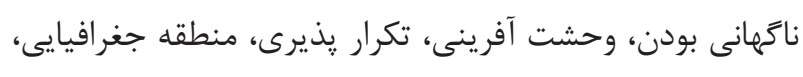

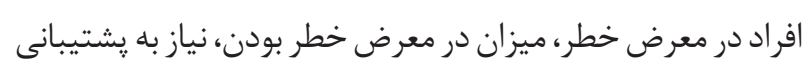

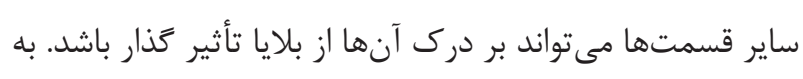
عقيده مشاركت كنندًان شناخت خصوصيات بلايا در نيروهاى

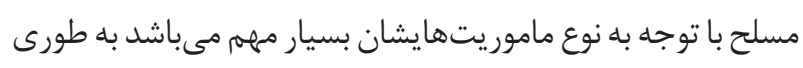

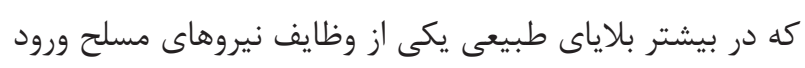


با علائم تنفسى به اورزانس آوردند به طورى كه بخش كودكان

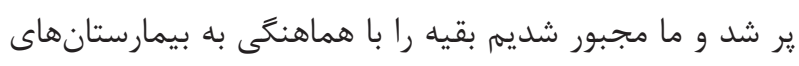

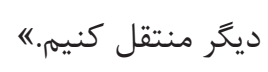

\section{r-V- ميزان در معرض خطر بودن}

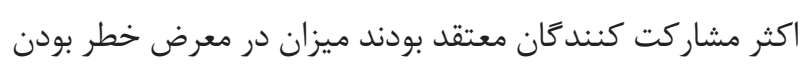

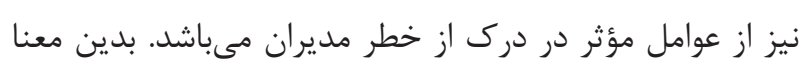

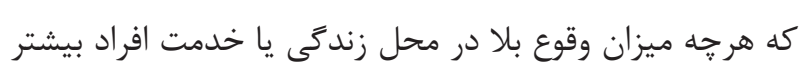
باشد و نسبت به آن خطر شناخت بِيدا مى كنند. يكى از مشاركت كنندكان اظهار داشت:

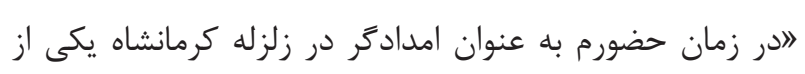

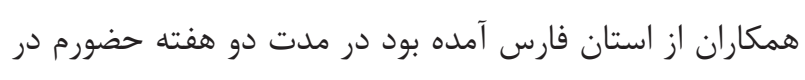
منطقه ما هر ساعت زلزله را داشتيم من بسيار سراسيمه مى فـدم

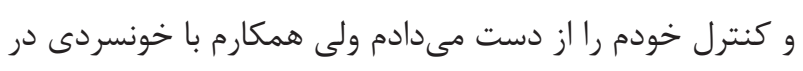

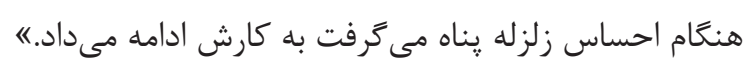

\section{r-1- نياز به يشتيبانى ساير قسمتها} به عقيده مشاركت كنند

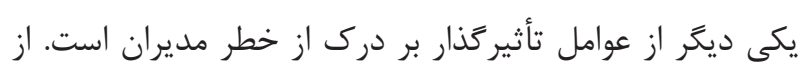

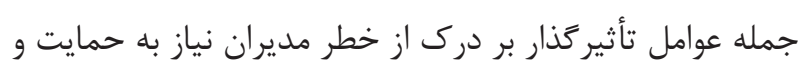
يشتيبانى ساير مراكز جهت تأمين تجهيزات - امكانات و يا انتقال

$$
\text { بيماران مىباشد. }
$$

يكى از مشاركت كنند

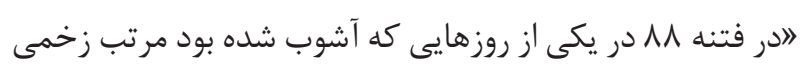

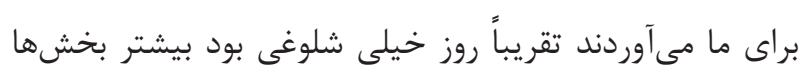

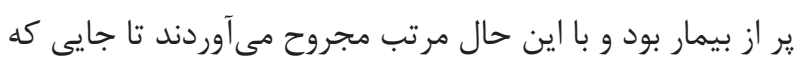

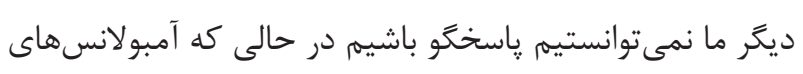

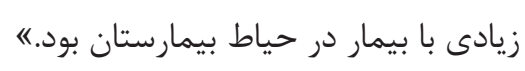

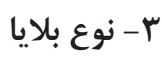

نوع بلايا يكى از طبقات اصلى به دست آمده در اين يزوهش بود.

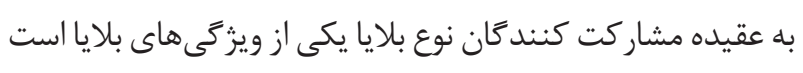

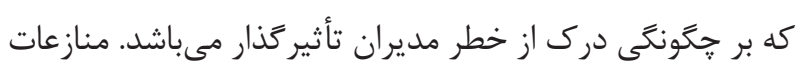

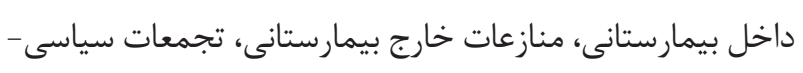

كه از ترس دجار حملههاى عصبى مىشدند.《

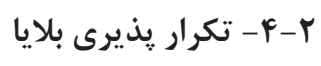

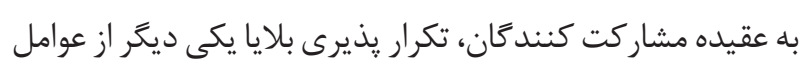

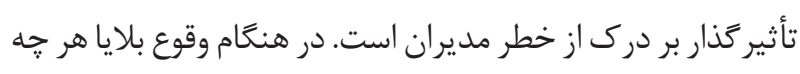

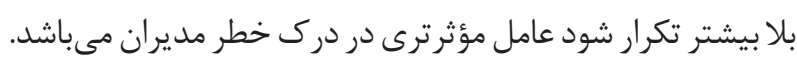
يكى از مشاركت كنند

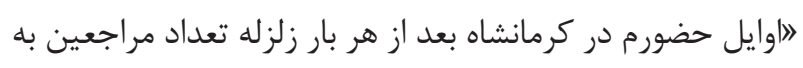

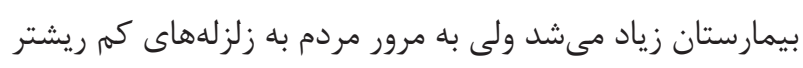

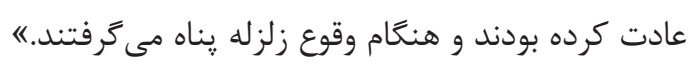

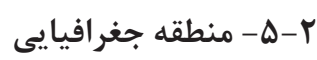
اكثر مشاركت كنندكان معتقد بودند هركاه افراد در منطقائه جغرافيايى زندكى مى كنند كه نوع خاصى از بلايا مكرر تكرار

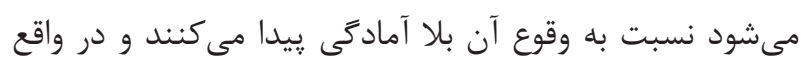

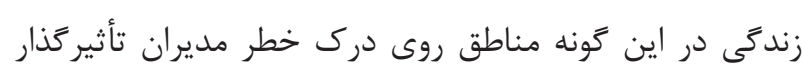
مى باشد. يكى از مشاركت كنند عان اظهار داشت:

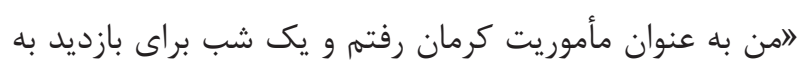

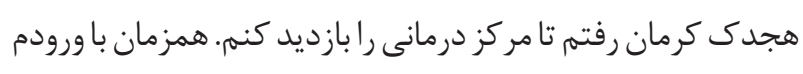

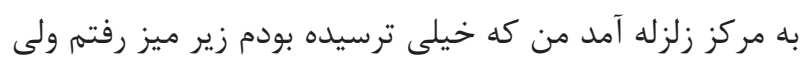

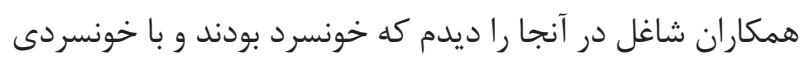

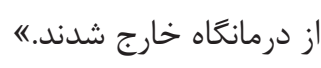

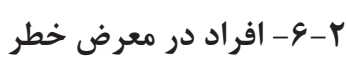

اكثر مشاركت كنندَان معتقد بودند افراد در معرض خطر خطر از

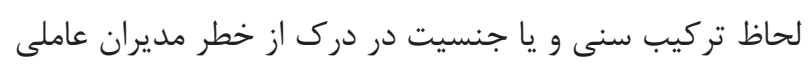

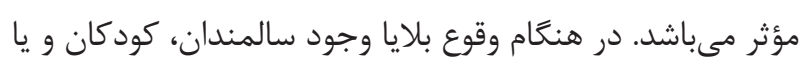
زنان در جمعيت در معرض خطر به دليل احتمال آسيب بيشتر از عوامل مؤثر در درك از خطر مديران مى دياشد. يكى از مشاركت كنند

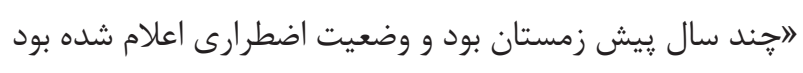
من در اورزانس مشغول خدمت بودم حدود ساعت • إصبح بود كه

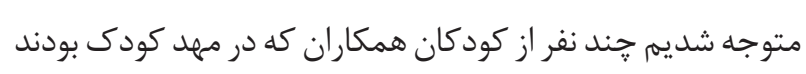


از استانها رفته بودم در آنجا زمان بازديد اعلام كردند دركيرى

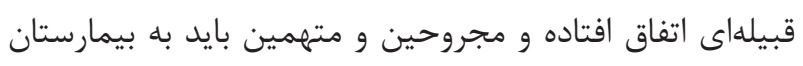

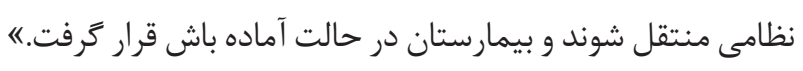

\section{r-ץ- تجمعات سياسى -مذهبى}

اكثر مشاركت كنند كان معتقد بودند تجمعات سياسى -مذهبى - تمديى نيز

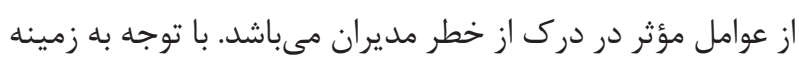

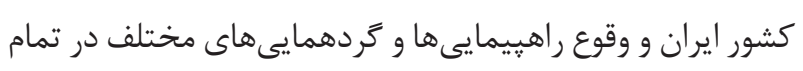

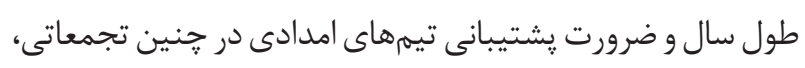
مراكز درمانى نظامى به عنوان واحدهاى امدادى در حالت آماده

باش بوده و همواره تعدادى نيروى درمانى نيز اعزام مى كنند. يكى از مشاركت كنند كان اظهار داشت:

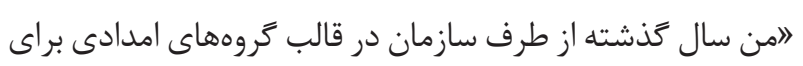
اربعين به مهران اعزام شدم و حدوداً يك هفته در آنجا بوديم. از

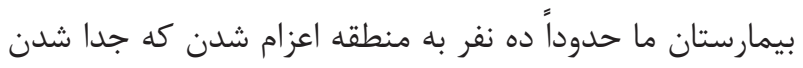
اين تعداد از بخشها با توجه به كمبود نيرو براى بيمارستان

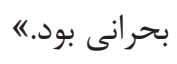

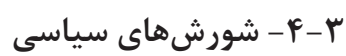

به عقيده مشاركت كنند ايجاد شده در جامعه كليه مراكز درمانى نظامى به لحاظ موضوعات

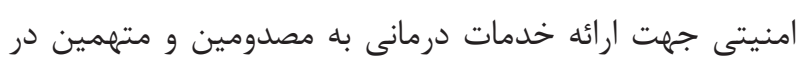

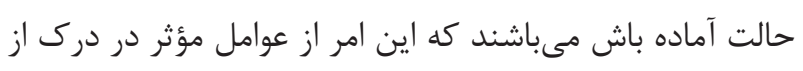
خطر مديران مى باشد. يكى از مشاركت كنندكان اظهار داشت:

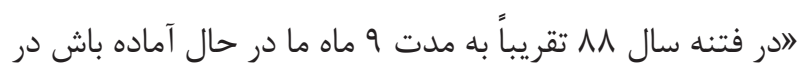

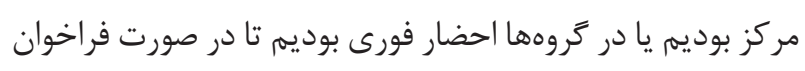

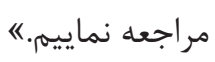

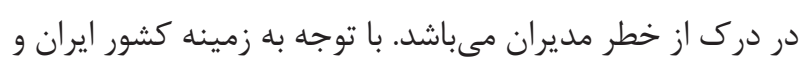

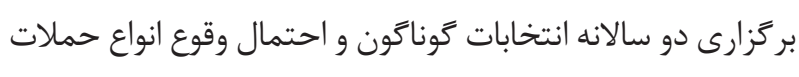

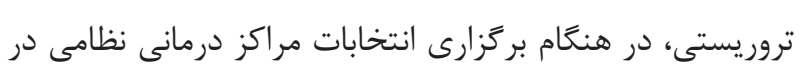

مذهبى، شورشهاى سياسى، برَزارى انتخابات و بلاياى طبيعى

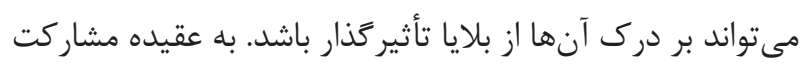

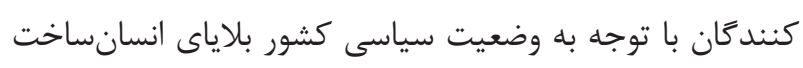
نسبت به بلاياى طبيعى اهميت بيشترى دارد.

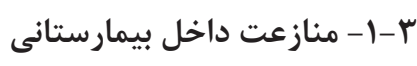

به عقيده مشار كت كنندًان منازعات داخل بيمارستانى از عوامل

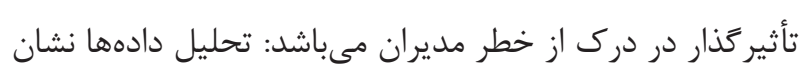

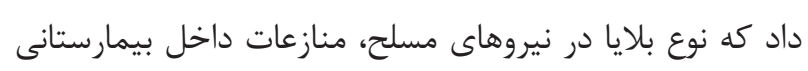

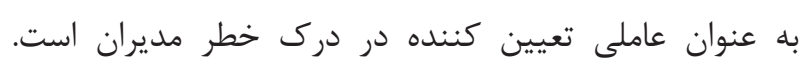

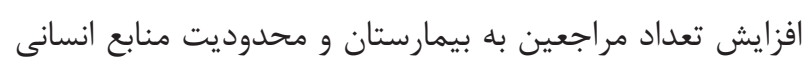
و تجهيزات و طولانى شدن ليست انتظار باعث افزايش ميزان نارضايتى مراجعين مى كردد كه اين عوامل از دلايل اصلى ايجاد

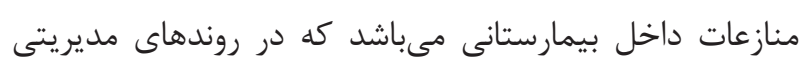

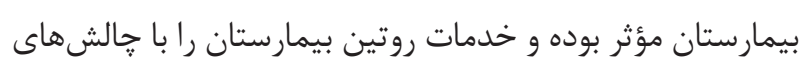
جدى مواجه مي كند. يكى از مشاركت كنند

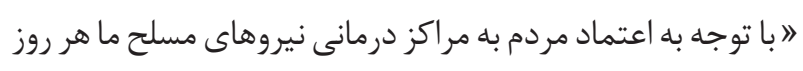

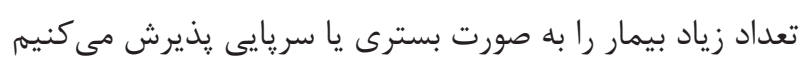

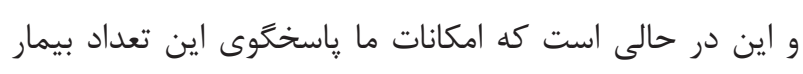

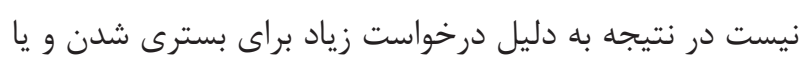

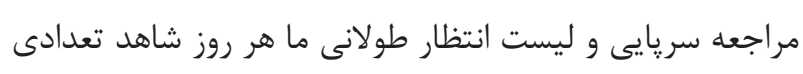

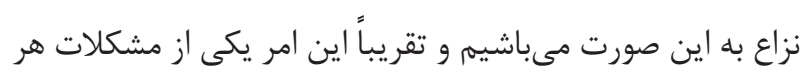
روزه ما مىباشد.ش

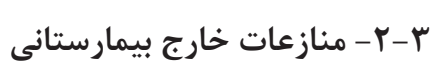

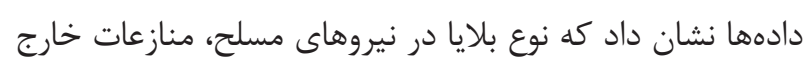

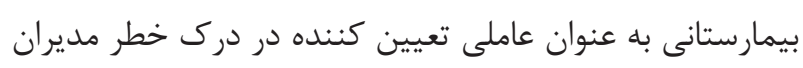
است. در هنحام وقوع منازعات اجتماعى مصدومين و متهمين بـنين

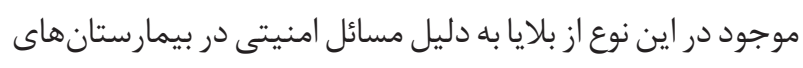

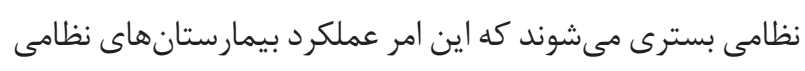

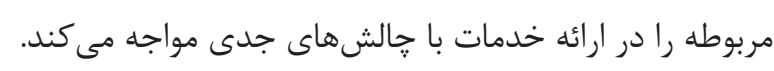
يكى از مشاركت كنند به عقيده مشار كت كنند 
در درك از خطر مديران مىباشد و در هنحام وقوع بلاياى طبيعى

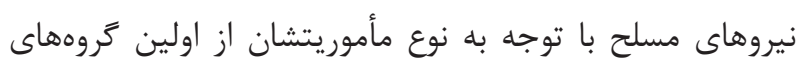

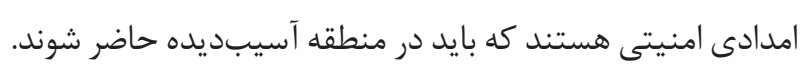
يكى از مشاركت كنند كان اظهار داشت:

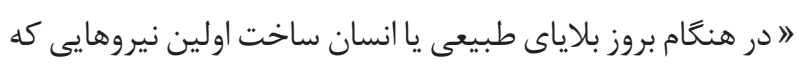

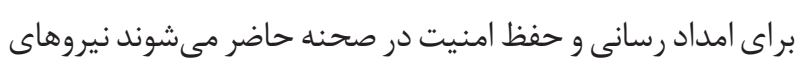

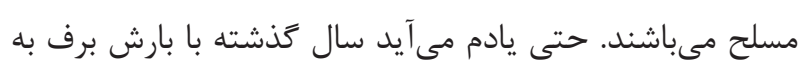

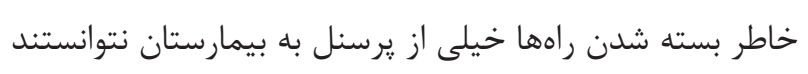

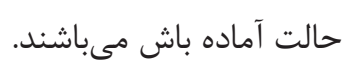
يكى از مشاركت كنند

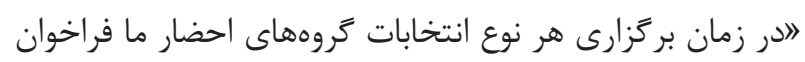

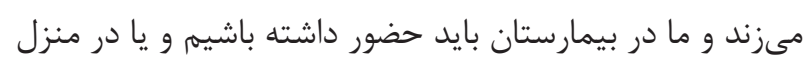

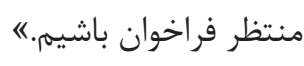
ب- ب- بلاياى طبيعى به عقيده مشاركت كنندكان وقوع بلاياى طبيعى از عوامل مؤثر

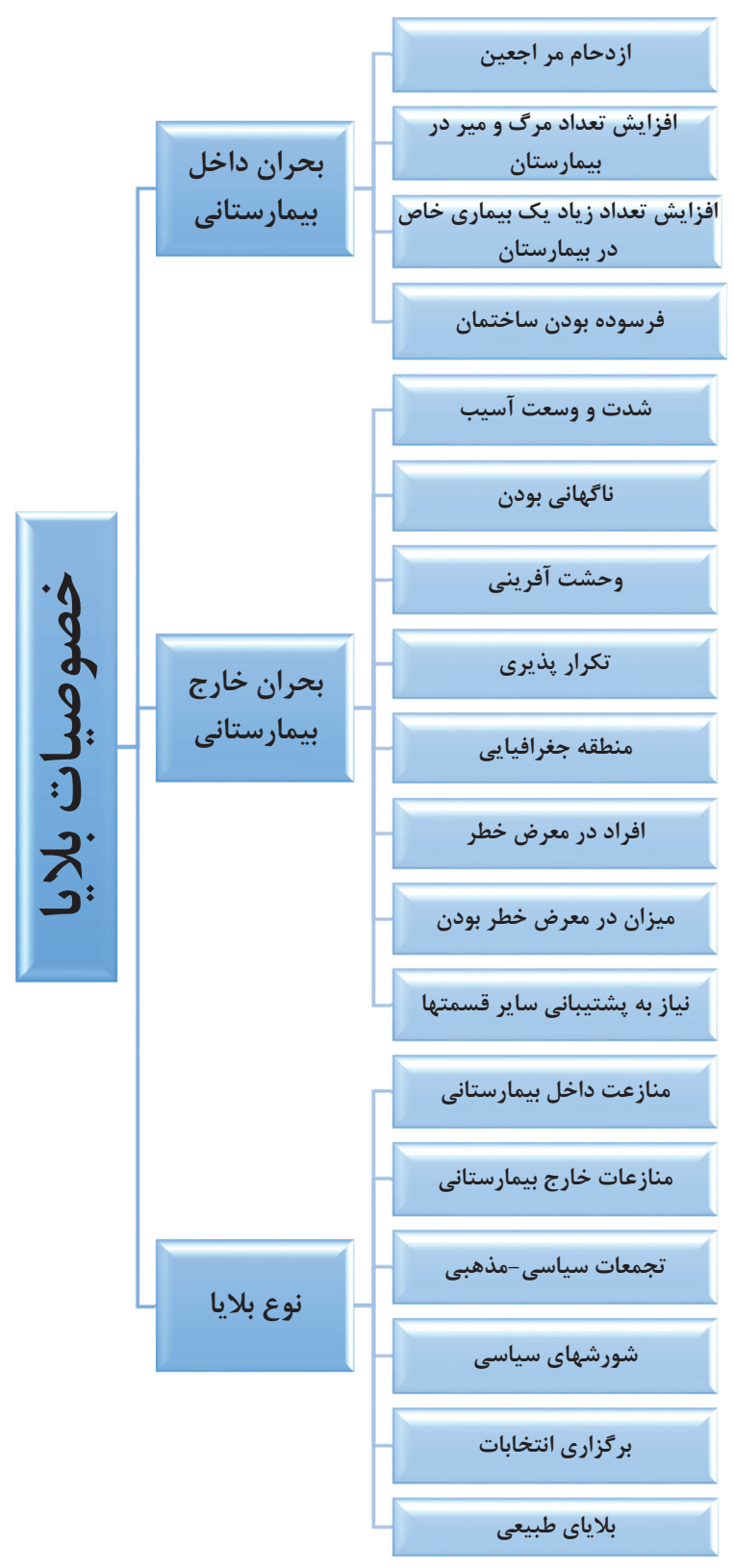


بلاياى پيشبينى نشده و حوادث احتمالى، بيشتر شده و افراد

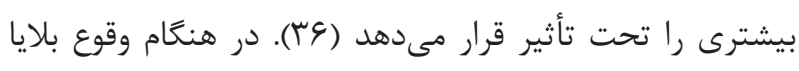

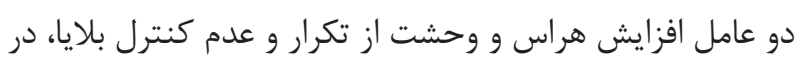

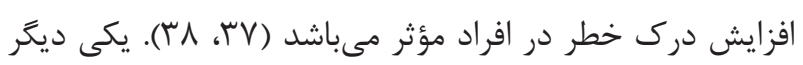

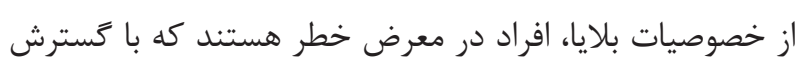

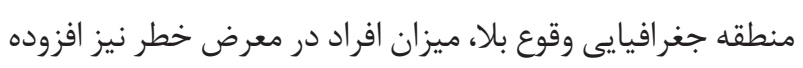

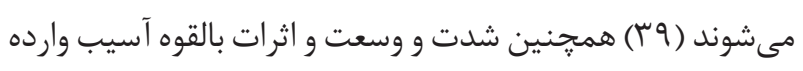

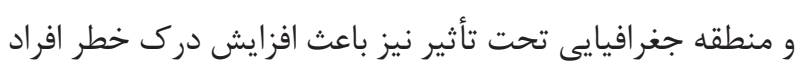

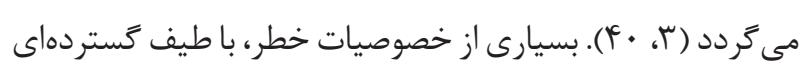

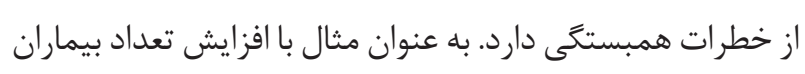

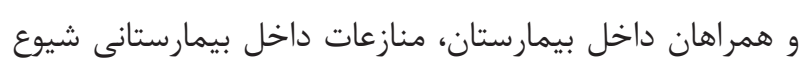

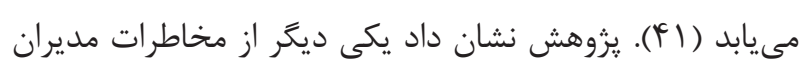

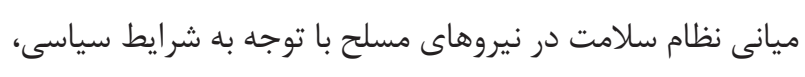

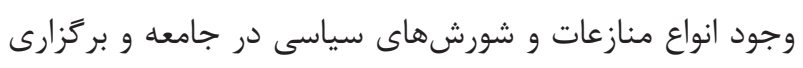

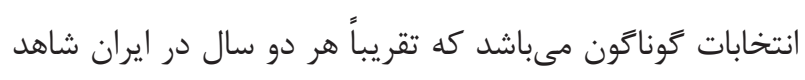
آن مىباشيمى كه اين عوامل خاص نيروهاى مسلح مىباشد.

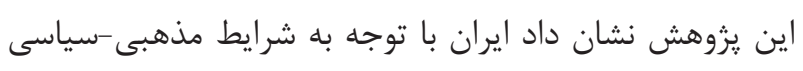

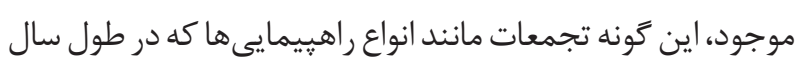

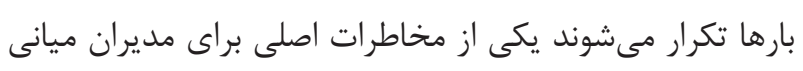

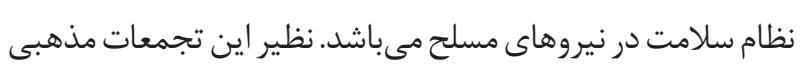

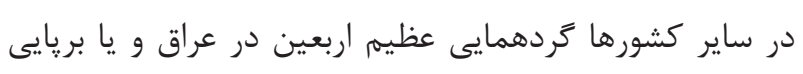
مناسك حج در كشور عربستان مىباشد كه براى مراكز خدمات

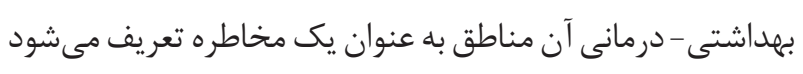
(هَّ). هدف اصلى بيمارستانها از شناخت ويزَّى مخاطرات و بلايا به حداقل رساندن خطر آسيب يا بيمارى و به حداكثر رساندن

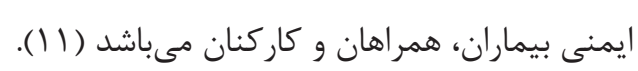
با شناخت خصوصيات بلايا در سيستمهاى بهداشتى سيستم

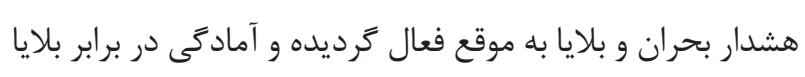

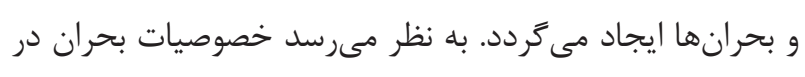
نظام سلامت نيروهاى مسلح نسبت به ساير سيستمهاى بهداشتى

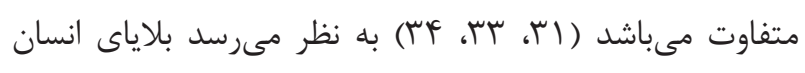

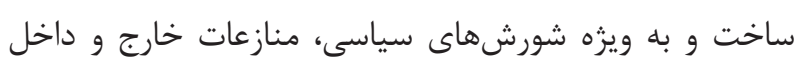
بيمارستانى و همجنين رويدادهاى خاص مانند بركزارى انتخابات

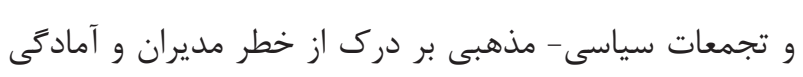

سر كارشان حاضر شوند و اين در حالى بود كه آمار مراجعين ما

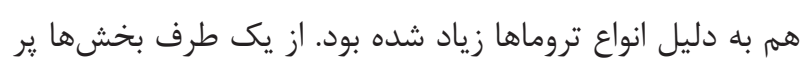

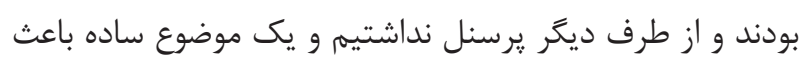
به هم خوردن نظم بيمارستان شده بود."

\section{بحث و نتيجه كيرى}

اين مطالعه، كيفى به روش تحليل محتواى قراردادى انجام شد و

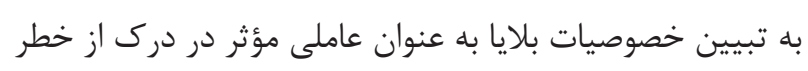

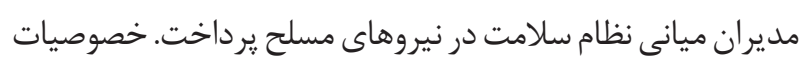

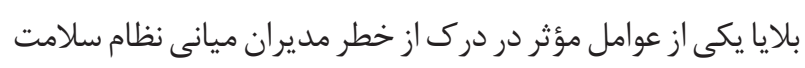
مىباشد كه در سيستمهاى بهداشتى درمانى نظامى و غيرنظامى مئى

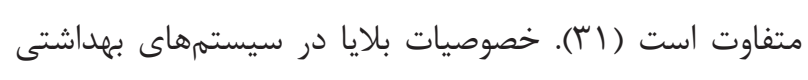
درمانى غيرنظامى با توجه به دستور العمل هاى كشورى و مطالعات

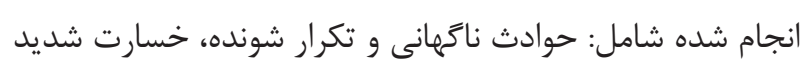

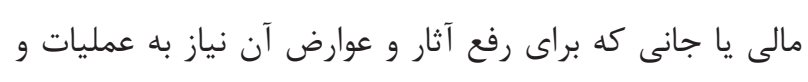

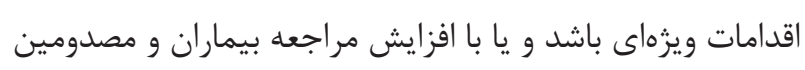

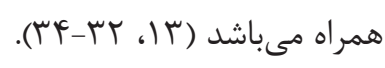
بر طبق يافتههاى اين مطالعه يكى از مأموريتهاى نيروهاى

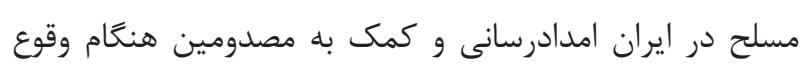

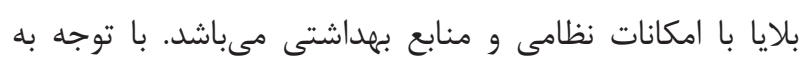
اين موضوع سيستم بهداشتى درمانى نيروهاى مسلح در زمره

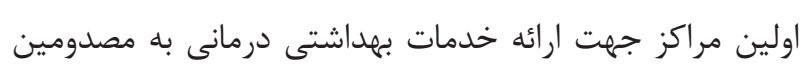

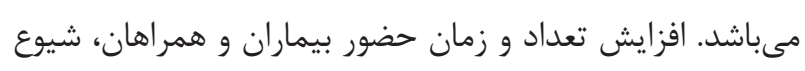

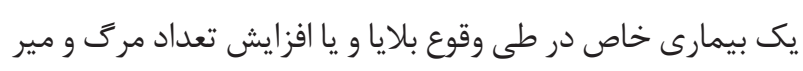

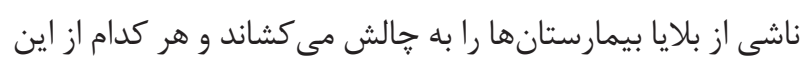
خصوصيات نوعى بحران داخلى براى بيمارستانها، تلقى مى گر دد

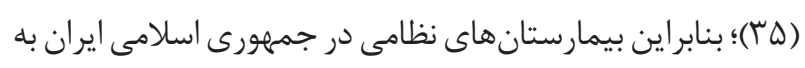

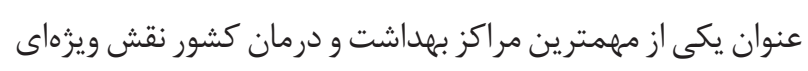

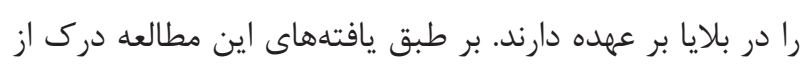

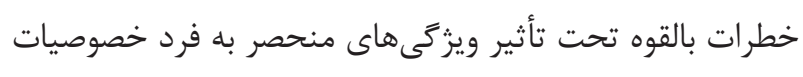

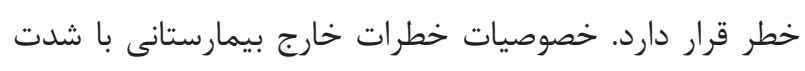

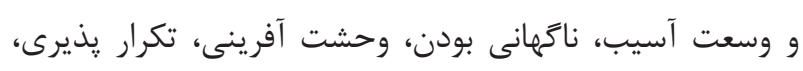

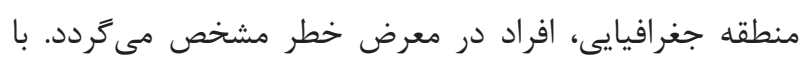

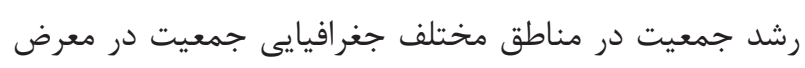




$$
\text { تشكر و قدردانى }
$$

اين مقاله بركرفته شده از يايان نامه كارشناسى ارشد رشته يرستارى

اورزانس مىباشد كه در دانشكده يرستارى آجا به شماره ثبت

و

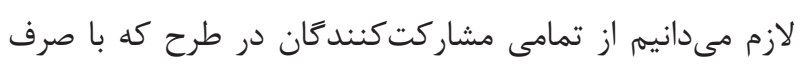

وقت كافى ما را در انجام مصاحبهها و ساير نظرخواهىها يارى

$$
\text { كردند، تشكر نماييم. }
$$

تضاد منافع

بدين وسيله محققين تصريح مى كنند كه هيج گَونه تضاد منافعى در خصوص يزوهش حاضر وجود ندارد.

\section{References}

1- IFRC witdS. What is a disaster? 2015 Available from: http://www. ifrc.org/en/what-we-do/disaster-management/about-disasters/ what-is-a-disaster/.

2- Wildavsky A, Dake K. Theories of risk perception: Who fears what and why? Daedalus. 41-60. 1990.

3- Slovic P, Peters E. Risk Perception and Affect. Current Directions in Psychological Science. 2016;15(6):322-5. http://dx.doi. org/10.1111/j.1467-8721.2006.00461.x

4- Holton GA. Defining Risk. Financial Analysts J. 2019;60(6):1925. http://dx.doi.org/10.2469/faj.v60.n6.2669

5- UNISDR. 2016-17 Biennium Work Programme Final Report. 2018.

6- Sullivan-Wiley KA, Short Gianotti AG. Risk Perception in a Multi-Hazard Environment. World Development. 2017;97:13852. http://dx.doi.org/10.1016/j.worlddev.2017.04.002

7- Indicators UoBCSa. belgium: Centre for Research on the Epidemiology of Disasters (CRED). 2014

8- Ferrer R, Klein WM. Risk perceptions and health behavior. Curr Opin Psychol. 2015;5:85-9. http://dx.doi.org/10.1016/j. copsyc.2015.03.012 www.ncbi.nlm.nih.gov/pubmed/26258160

9- European Union. Sendai Framework for Disaster Risk Reduction 2015-2030 18 March 2015. Available from: https://ec.europa. eu/echo/partnerships/relations/european-and-internationalcooperation/sendai-framework-disaster-risk-reduction_en.

10- Cliff BJ, Morlock L, Curtis AB. Is there an association between risk perception and disaster preparedness in rural US hospitals? Prehosp Disaster Med. 2009;24(6):512-7. http://dx.doi. org/10.1017/s1049023x00007433 www.ncbi.nlm.nih.gov/ pubmed/20301069

11- Alzahrani F, Kyratsis Y. Emergency nurse disaster preparedness during mass gatherings: a cross-sectional survey of emergency nurses' perceptions in hospitals in Mecca, Saudi Arabia.

$$
\begin{aligned}
& \text { آنان در بلايا مؤثر است. خصوصيات بلايا در نظام سلامت نيروهاى } \\
& \text { مسلح كاملاً وابسته به زمينه (Content Based) كشور ايران بوده و } \\
& \text { لازم است تا مداخلاتى در خصوص ويزگگى هاى بلاياى انسان ساخت } \\
& \text { مستخرجه از اين يزوهش انجام گيرد. در اين مطالعه، خصوصيات } \\
& \text { بلايا از عوامل موثر بر درك از خطر مديران ميانى نظام سلامت } \\
& \text { در نيروهاى مسلح به روش كيفى، تبيين و دسته بندى شده است } \\
& \text { و بايد به 1 | زير گروه آن دقت نموده و برنامهريزى مناسب در } \\
& \text { اين زمينه انجام گردد. به دليل محدوديت يزوهشگران، عرصه اين } \\
& \text { مطالعه مديران ميانى نظام سلامت نظامى در شهر تهران بودند. } \\
& \text { ييشنهاد مى } \\
& \text { مسلح در كل كشور انجام گردد. }
\end{aligned}
$$

BMJ Open. 2017;7(4):e013563. http://dx.doi.org/10.1136/ bmjopen-2016-013563 www.ncbi.nlm.nih.gov/pubmed/28400457

12- Mousavi S, Zaeemipour M, Zali M. Evaluate Nurses' Capability Based on Accreditation Standards by Nursing Administrators at AJA-Military Hospitals During 2011. J Nurse and Physician within War. 2012;19:14-9.

13- Khanakeh H. Hospital Preparedness for Disaster and Disaster Country Program. Tehran: University of Social Welfare and Rehabilitation Sciences; 2014.

14- Rahmati-Najarkolaei F, Moeeni A, Ebadi A, Heidaranlu E. Assessment of a Military Hospital's Disaster Preparedness Using a Health Incident Command System. Trauma Monthly. 2016;22(2). http://dx.doi.org/10.5812/traumamon.31448

15- Djalali A, Castren M, Hosseinijenab V, Khatib M, Ohlen G, Kurland L. Hospital Incident Command System (HICS) performance in Iran; decision making during disasters. Scandinavian J Trauma, Resuscitation \& Emergency Medicine. 2012;20(1):14.

16- Mehrabi F, Ghasemi M, Rezaee M. The assessment of readiness indicators in military hospitals against natural disasters in Iran. J Mil Med. 2015;17(1):35-40.

17- Amerion A, Aghighi A, Tofihi S, Sadeghi AA, Shahedi A, Rasekh F. Assess the disaster preparedness of the selected military hospitals. J Army Univ Med Sci. 2014;11:353-6.

18- Seyedin SH, Zaboli R, Malmoon Z, Rajabifard F. General Hospital Managers' Perception Regarding Crisis Management at Iran and Tehran University of Medical Sciences. J Hospital. 2014;2(57):95102.

19- Sadeghi M, Gholamhoseini L, Esmaeel Zali M, Mehrabi N, Nejati B. The Survey on the Vulnerability of Military Hospitals in Crisis Situation and War and Offer Suitable Solutions and Mission in These Situations in the Second Semester of 1391. Paramedical Sci \& Military Health. 2015;10(1):24-30. 
20- Slovic P, Fischhoff B, Lichtenstein S. Why Study Risk Perception? Risk Analysis. 1982;2(2):83-93. http://dx.doi. org/10.1111/j.1539-6924.1982.tb01369.x

21- Phibbs S, Kenney C, Severinsen C, Mitchell J, Hughes R. Synergising Public Health Concepts with the Sendai Framework for Disaster Risk Reduction: A Conceptual Glossary. Int J Environ Res Public Health. 2016;13(12). http:/dx.doi.org/10.3390/ ijerph13121241 www.ncbi.nlm.nih.gov/pubmed/27983666

22- Krippendorff K. Content analysis: An introduction to its methodology: Sage publications; 2018.

23- Adel Mehraban M. A review of qualitative content analysis and its application in research. Isfahan University of Medical Sciences \& Health Services. 2015.

24- Graneheim UH, Lundman B. Qualitative content analysis in nursing research: concepts, procedures and measures to achieve trustworthiness. Nurse Educ Today. 2004;24(2):105-12. http:// dx.doi.org/10.1016/j.nedt.2003.10.001 www.ncbi.nlm.nih.gov/ pubmed/14769454

25- Hassanzadeh Rangi N, Allahyari T, Khosravi Y, Zaeri F, Saremi M. Development of an Occupational Cognitive Failure Questionnaire (OCFQ): evaluation validity and reliability. Iran Occupational Health. 2012;9(1):29-40.

26- Instructions Order on how to select professional executives, $579095(13 / 4 / 1395)$.

27- Neuendorf KA, Kumar A. Content Analysis. The International Encyclopedia of Political Communication2016. p. 1-10.

28- MSc1 M. Evaluation of qualitative data Reserch of Student at Sabzevar University of Medical Sciences. Winter 1390;44(3):506.

29- Sarmad ZA. Research Methods in Behavioral Sciences. Tehran: Publishing House; 1376.

30- Wilson V. Research Methods: Content Analysis. Evidence Based Library and Information Practice. 2016;11(1(S)). http://dx.doi. org $/ 10.18438 / \mathrm{b} 8 \mathrm{cg} 9 \mathrm{~d}$

31- Chehry N. Emergency management and planning system in hospital. Journal of the Army Medical Nursing Faculty. 2011.
32- Khankeh HG. National Hospital Risk Management Guide Based on Accreditation Indicators. Education MoHaM. Ministry of Health and Medical Education. 2017.

33- Ezzati E, Kaviannezhad R, Karimpour H, Mohammadi S. Preparedness of crisis and disaster management in social security hospitals in Kermanshah in 2016: A short report. J Rafsanjan Univ Med Sci. 2016;15(6):583-90.

34- Sabzghabaie A, Kondori A, Shojaee M, Hatamabadi H, Amini A. Hospital safety in hospitals affiliated with Shahid Beheshti University of Medical Sciences in 2011-13. Pajoohandeh J. 2013;18(2):83-7.

35- Khan I, McLeod RD. Managing hajj crowd complexity: Superior throughput, satisfaction, health, and safety. Kuwait Chapter of Arabian Journal of Business and Management Review. 2012;33(853):1-15.

36- Öztekin SD, Larson EE, Altun Uğraş G, Yüksel S, Savaşer S. Nursing educators> perceptions about disaster preparedness and response in Istanbul and Miyazaki. Japan J Nurs Sci. 2015;12(2):99-112. http://dx.doi.org/10.1111/jjns.12054

37- Slovic P, Weber E. Perception of risk posed by extreme events. 2002. Regulation of Toxic Substances and Hazardous Waste (2nd edition)(Applegate, Gabba, Laitos, and Sachs, Editors), Foundation Press, Forthcoming. 2016.

38- Slovic P. Perception of risk. Science. 1987;236(4799):280-5. http://dx.doi.org/10.1126/science.3563507 www.ncbi.nlm.nih. gov/pubmed/3563507

39- Gurian PL. Risk perception, risk communication, and risk management. 2012.

40- Rohrmann B. Risk perception, risk attitude, risk communication, risk management: A conceptual appraisal. 15th Internaional Emergency Management Society (TIEMS) Annual Conference2008.

41- Slovic P, Fischhoff B, Lichtenstein S. Characterizing perceived risk. Perilous progress: Managing the hazards of technology. 1985:91-125. 